LWSA

PAPER - OPEN ACCESS

\title{
Bintang Radio Contest as Effort to Build a National Identity, 1950s
}

\author{
Author : Dhanang Respati Puguh and Rafngi Mufidah \\ DOI $\quad: 10.32734 /$ lwsa.v3i4.1126 \\ Electronic ISSN $\quad: 2654-7066$ \\ Print ISSN : :2654-7058
}

Volume 3 Issue 4 - 2020 TALENTA Conference Series: Local Wisdom, Social, and Arts (LWSA)

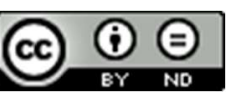

This work is licensed under a Creative Commons Attribution-NoDerivatives 4.0 International License.

Published under licence by TALENTA Publisher, Universitas Sumatera Utara

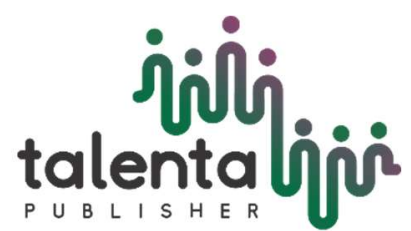




\title{
jibiti talentalion \\ LWSA Conference Series 03 (2020)

\section{Bintang Radio Contest as Effort to Build a National Identity, 1950s}

\author{
Dhanang Respati Puguh ${ }^{\mathrm{a}}$ Rafngi Mufidah ${ }^{\mathrm{b}}$ \\ ${ }^{a}$ Department of History, Faculty of Humanities, Universitas Diponegoro, 50275, Indonesia \\ ${ }^{b}$ Master Program of History, Faculty of Humanities, Universitas Diponegoro, 50275, Indonesia \\ dhanang.respati@live.undip.ac.id, rafngimufidah@live.undip.ac.id
}

\begin{abstract}
This article discusses Bintang Radio Contest organized by Radio Republik Indonesia in the 1950s. The article was compiled using historical methods and using a range of contemporary sources such as magazines (Berita Radio, Mimbar Indonesia, Star Weekly, and National), articles, monographs, and books. Bintang Radio contest was held due to the fact that Indonesian people had not acquired adequate music and vocal education. The main purpose in organizing Bintang Radio Contest is to provide motivation and understanding to singers to sing professionally, in which they must have provisions on musical techniques and insight; changing people's perceptions; and exchange ideas about music. Bintang Radio Contest was held by selection from preliminary in the regional to final rounds in the national level by certain evaluation criteria. The organizing of Bintang Radio Contest as an effort to establish a national identity.
\end{abstract}

Keywords: Radio Republik Indonesia; Bintang Radio; National Culture; Music Art.

\section{Introduction}

In accordance with the formation of the Unitary State Republic of Indonesia, "the nation state is seen as a protector culture and a barrier to cultural imperialism" [1]. In thih regards, the development of Indonesian culture has become decisive issue that is thought-provoking to discuss and pursue at the beginning of Indonesian independence. Radio Republik Indonesia (RRI), was established in a conference held in Jakarta on September 11, 1945, also has responsible in developing Indonesian culture. It was therefore not surprising that Sen and Hill [2] stated that RRI was established with the aim of supporting the Indonesian Government's programs. RRI is not only a political medium, but also a cultural medium for the Indonesian government. In its position as a government cultural media, RRI has the responsible to make efforts towards the collection and broadcasting of regional culture so that it is acknowledged by all Indonesian people. In this regard, RRI obliged to explore all the richness of the indigenous culture of the Indonesian nation so that it could be introduced to the community. It was not intended to revive regionalism, but was part of an effort to shape a national culture. Furthermore, a living regional culture required to be broadcasted widely to all Indonesian people, so that an assimilation process could emerge then formulate a new national culture. Therefore, RRI should be an active channel to execute these efforts [3]. In line with the current policies, RRI organizes cultural broadcasts, following the terms cited by Yampolsky [4] were including National Music, Regional Entertainment, and Regional Music and Theater. RRI also held a Bintang Radio Contest.

Cultural broadcasts organized by RRI have received attention from Sutton [5], Mardianto and Darmanto [6], and Puguh [7]. Sutton has discussed Javanese musical broadcasts on RRI Yogyakarta, Surakarta, Purwokerto, Surabaya, and Semarang, each of which shows its regional identity. Mardianto and Darmanto discusses the Javanese radio literary tradition, which, among other things, discussed Sandiwara Daerah broadcasts of RRI Yogyakarta. Puguh (2015) in one of the chapters of his dissertation discusses broadcasts of Javanese performing arts (karawitan, wayang wong, and wayang kulit purwa) RRI Surakarta; and in his article (2017) discusses the role of RRI Surakarta in efforts to form a national culture during the 1950-1960s period. Unlike the previous studies, this article discusses Bintang Radio Contest, as the most popular program in the 1950s. The event, was held at the national level since 1951, it was the climax of RRI anniversary celebration. The event also broadcasted nationally [8]. To achieve a comprehensive understanding, this article consecutively discusses the discourse on Indonesian cultural development; background, objectives, and implementation of Bintang Radio Contest; importance of Bintang Radio Contest for the development of Indonesian music; and followed by a conclusion. 


\section{Discourse on Indonesian Cultural Development}

At the beginning of independence, various thoughts and movements emerged to find a formulation for the development of Indonesian culture. In the midst of the revolution, meetings were held to discuss cultural development, namely: Permusyawaratan Kebudayaan (Cultural Consultation) in Sukabumi in 1945 and Permusyawaratan Pendidikan (Educational Consultation) in Surakarta in 1947. Persistent efforts to build Indonesian culture were also carried out by establishing cultural institutions by various circles in several regions. In Magelang, Lembaga Kebudayaan Kedu (Kedu Cultural Institute) was formed in 1946 with activities covering various branches of the arts. In Yogyakarta, Badan Permusyawaratan Kebudayaan (Cultural Consultative Affairs) was formed in 1946 which was engaged in various branches of art, particularly painting, theater, and sound art [9].

In 1948 the discourse on the development of Indonesian culture was getting more appealing. It was indicated by the number of writings about basis and orientation of Indonesian cultural development which partly focuses on the fields of arts, language, and the establishment of cultural institutions which aim to build and flourish Indonesian culture. Apart from these discourses, in 1948, cultural enthusiasts formed a cultural institution named the Institut Kebudayaan Indonesia (Indonesian Cultural Institute). This institution aims to build and flourish Indonesian culture. Discourses on the development of Indonesian culture were flourishing. Furthermore, on 6 May 1948, a deliberative meeting was held in Magelang to discuss the agenda of Kongres Kebudayaan Indonesia (Indonesian Cultural Congress) [10].

Three days before the 1st Indonesian Cultural Congress which coincided with the third anniversary of Indonesia's independence, Ki Hadjar Dewantoro reaffirmed the orientation of national cultural development. According to him, along with the independence that has been achieved, the development of the state and nation of Indonesia should be executed, which was none other than the development of Indonesian culture. Regional culture is abundant source for building Indonesian culture. Therefore, it is necessary for Indonesian nation to mantain and develop its culture. To achieve this goal, it is essential to have cultural institutions as well as cultural education and teaching at all levels of education [11].

On 20-25 August 1948, the 1st Indonesian Cultural Congress was held in Magelang which was officially organized by the government. During the event, ideas about culture emerged from Indonesian national leaders and cultural figures, as well as attempted to formulate Indonesian culture in a post-colonial context. In the First Indonesian Cultural Congress, various topics related to cultural development were discussed by experts. Some of them were Armijn Pane who discusses cultural institutions, B. Sitompul, Anas Ma'ruf, B. Resobowo, Abu Hanifah, and Sindoesawarno, each of them discusses branches of art which include sound, literature, and fine arts, and plays, as well as the establishment of arts academies [12]. The First Indonesian Cultural Congress succeeded in formulating three conclusions related to cultural institutions. First, give approval on the establishment of the Lembaga Kebudayaan Indonesia (Indonesian Cultural Institute). Second, encourage the government to immediately establish an arts academy; and third, recommend the government to establish an independent ministry for cultural field [13].

The discourses on the development of Indonesian culture were flourishing, respectively after the holding of the Indonesian Cultural Congress I. Cultural observers and artists immediately followed up on result of decisions of the Indonesian Cultural Congress I. They took initiatives to create Lembaga Kebudayaan Indonesia (Indonesian Cultural Institute) which became a forum for cultural activities and cultural conferences [14]. Intellectuals and artists also gathered at the studio to exchange ideas. Aside from various official channels such as congresses and conferences, they discussed actual topics related to the development of Indonesian culture. Culture and art, as well as the role of art in the creation of a new Indonesian identity, were essential topics discussed by intellectuals and artists at these studios. The mass media has also become an important 'vehicle' for debate in order to set the foundations of Indonesian culture free from colonial burdens. Mimbar Indonesia was one of the mass media that pays much attention to the discourse of shaping Indonesian culture. Some issues on cultural heritage, progress and modernity, polemics about aesthetics, Indonesian music, cultural heroes, and decolonization were frequently discussed in Mimbar Indonesia. The writings featured in Mimbar Indonesia offered a unique impression of the new age state and the voices of the new Indonesians. They provided concrete steps to create an Indonesian culture [15].

The discourse on the development of Indonesian culture in Mimbar Indonesia in 1950 was no less than represented of Supomo's ideas, who was an editor in chief of the magazine. He said that state leaders should establish a cultural policy which was the embodiment of the fostering of a new Indonesian state and society on the foundations of a new culture, which includes arts, literature, and morality. The Indonesian nation could not return to the past. However, cultural heritage is a background of Indonesian society that should be maintained. Therefore, the management of cultural heritage is one of the steps that needs to be done as a cultural politics [16].

Since the holding of Indonesian Cultural Congress in 1948, decolonization has increased its urgency and needed for practical decision-making to bring about Indonesian culture. As the cultural clause enclosed in Undang-undang Dasar Sementara 1950 (UUDS, Provisional Consititution) which used the same words as Konstitusi Republik Indonesia Serikat 1949 (Constitution of the United States of Indonesia), in the early 1950s the Indonesian government would protect the freedom to evolve culture, arts, and science. Based on this principle, the Indonesian government promoted the development of nationalism in term of culture, arts and sciences [17]. The Indonesian government carried out development in the cultural sector under the authority and coordination of the Ministry of Education, Teaching and Culture. National cultural development in the arts field was mainly conducted by 
establishing art schools and art education in formal schools.

\section{Bintang Radio Contest: Background, Purposes, and Implementation}

Prior to the implementation of Bintang Radio Contest, the Government of Indonesia had paid attention to the world of music, notably vocal or singing. One of those efforts was to establish policies towards conservatory music education through formal education in public schools, namely: by designing music a compulsory subject in schools. Apart from that, the Indonesian government also brought music teachers to various regions, such as: Surakarta, Yogyakarta, Bandung, Jakarta, and so forth. Through formal education, the government expected to provide regular and profound music education to the future generations. Thus, it was expected to produce top-quality artists, in field of music, specifically in the vocal arts. However, the step was unsuccessful due to the irregular implementation in schools [18]. The music art lessons only implement once a month in schools, in fact, it was frequently replaced by painting lessons. This situation occurs mainly because the lack of public attention to music education. In general, people do have an interest in music, especially singing. But unfortunately, they do not realize that to gain an outstanding vocal competence, singers have to study regularly [19].

In addition to the lack of public awareness, apparently the teachers who were brought in had not acquired a proper music education. Most of them only learn from books distributed by the Ministry of Education, Teaching and Culture. They generally have not acquired the basic theory of music directly, so they could not carry out the practice of playing music or singing in a proper and a correct way [20].

Therefore, RRI as a radio station which supports all government policies later initiated a more open program intended to the public, namely by holding a vocal music competition. The competition was known as Bintang Radio Contest. Bintang Radio Contest was a form of RRI's attention to the development of music and vocal arts in Indonesia. The objectives of organizing Bintang Radio Contest were as follows. The first goal was to give motivation and understanding the singers for better performance. To be a good singer, someone has to understand musical techniques and insight. If these two conditions were attained, it would be easy for singers to interpret the song. The second objective was to change people's perceptions about figure of singer. In the 1940s, people still considered singers including pesindhen as people who could only play around. Oftentimes, they were even seen as having low morals [21]. This viewpoint becomes a stereotype for art. Society finally identifies art as an inferior item. In consequences, those with higher education feel embarrassed to be involved in the world of art, especially singing [22]. The third objective was as a media for singers and musicians from various regions to interact and exchange ideas about music. Thus, it was expected that there would be a deep feeling within the hearts of singers and musicians to jointly strengthen the art of music in Indonesia. From the meeting, the Government of Indonesia also hoped that Indonesian artists, notably musicians and singers, would earn a proper place to develop their talent and get a better life [23].

The first Bintang Radio Contest was held in Surakarta in 1947. Since 1951, this event has been held in Jakarta for the national level. Therefore, the year of 1951 known as the first year of Bintang Radio Contest. Bintang Radio Contest was divided into three categories, namely: seriosa, keroncong, and pop music. The division was intended to provide a channel for singers who certainly have a tendency towards different types of vocals and interests [24]. Each category was divided based on gender, namely men and women. Therefore, the committee prepared several songs with various characters and had a lot of pitch shifting or known as modulation. Several songs such as, Citra, Gugur Bunga, Kr. Moritsko, Wanita, Dahaga, Fajar Harapan, and Malam Syahdu were chosen because they were considered to have a high level of difficulty. In addition, the committee also permitted the participants to choose the song [25]. In 1965, in order to improve the quality of singers, prominently seriosa category, the types of competition were further divided into several sub-categories. For female singers, it consists of soprano, mezosopran, and alto, while for male it consists of tenor and baritone. Thus, in the 1965 Bintang Radio contest for Seriosa category, the championships of Seriosa soprano, seriosa mezosopran, and seriosa alto were for women, meanwhile Seriosa Tenor and Seriosa Baritone were for men. For some regions this change was complicated, according to the policies of RRI Directorate, several stations such as Medan, Makassar, Bandung, Jakarta and Yogyakarta could implement it, so that they could delegate representatives from their regions [26].

In line with the demand in performing songs with a high level of difficulty, the committee also set very detailed assessment criteria. There were three main aspects of assessment in Bintang Radio Contest, including: sound, song presentation, and pronunciation of lyrics. Aspects of voice included accuracy of tone, tone of voice, and breathing technique. Song performance included accuracy in presenting dynamic signs of the song, tempo, and soul of the lyrics. Meanwhile, the pronunciation of the lyrics included the accuracy of the pronunciation of the words and their accents. Based on these three aspects of assessment and high criteria for each aspect, it was hoped that the selected candidate of Bintang Radio were highly qualified and capable in vocal processing. To achieve this goal, the committee also prepared qualified judges in each category [27].

Bintang Radio Contest was carried out in several phases. Before the final performance of Bintang Radio, the selection was held in the regional level. In some areas the preparations for the Bintang Radio Contest were held in two to three months before heading to national level. Those who earned the highest score from each category were delegated to Jakarta to represent their area [28]. The selection of Bintang Radio will be continued for the next period, such as the prior contest held by RRI Yogyakarta in 1965. Selection for Bintang Radio in Yogyakarta in 1965 has been begun since July 12 and the final was held on July 29 and 30. Both preliminary, semi-final, and final selections were held in the RRI studio and were not attended by the audience. This is done 
so that the jury could accomplish ideal assessment towards participants. However, the public still could watch the winner who represents their region, because the committee of Bintang Radio Contest has collaborated with the Dwidasawarsa committee for Independence of the Republic of Indonesia. The winners were announced as well as introduced to the general public, which was held on August 2, 1965 at Panggung Kesenian Terbuka Pekan Raya [29].

At the preliminary stage selection, all participants were accompanied by piano music, meanwhile keroncong by keroncong ensemble. At Final Night of Bintang Radio in Jakarta, the finalists from all categories received a complete orchestral accompaniment consisting of 30-40 players [30]. RRI then presented an event entitled "Malam Panggung Gembira" which was enlivened by the winners. In this occasion, the committee distributed prizes to the winners. The event, which is held every September 13 and broadcasted nationally at 20.30 WIB [31]. In Bintang Radio 1955, apart from the Malam Panggung Gembira there was also a Pameran Musik which was played by a joint orchestra from RRI consisting of music players from various studios [32].

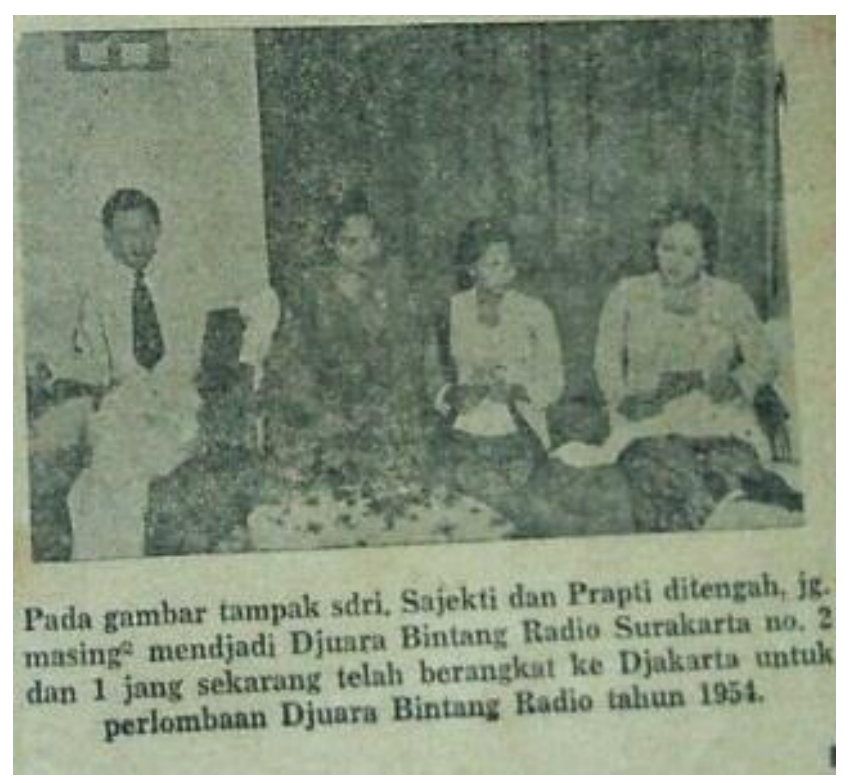

Fig 1. Bintang Radio Surakarta who were delegated to Jakarta

(Source: Berita Radio, August 1954).

Before going into the preliminary round, all participants received guidance from the trainer who has been prepared by the committee. The training, which was held for several days, was intended to provide in-depth knowledge about vocal techniques. This was due to RRI's commitment to produce outstanding singers with vocal abilities and musical insight. Furthermore, Bintang Radio Contest at the National Level was begun with a preliminary round, later, seven participants from each category will be selected to compete in the Final Night of Bintang Radio Contest which was held every September 11.

Until the fourth year of the event, namely in 1954, the Bintang Radio Contest consistently received a tremendous response from the public. As can be seen from the participants who came from various regions and professions; ranging from civil servants to RRI employees and students. According to records of Central RRI in 1954, the total participants who took part in the selection in the regions, namely: Medan, Padang, Bukittinggi, Palembang, and Yogyakarta, was more than 400 participants [33]. Meanwhile, the total number of participants delegated to Jakarta was 55 people. This number continues rising every year, in previous years, approximately 20 to 30 participants were delegated to Jakarta from all regions. [34]. Meanwhile, the participants of Bintang Radio Contest in 1955 were 1.5 times more than the previous year. In 1955, the participants of Bintang Radio Contest were 75 people. They came from 16 studios (the total of studios was 22) throughout Indonesia [35].

Bintang Radio Contest was the most awaited event for both singer and society. This could be seen from the venue for Final Night of Bintang Radio Contest, both at regional and national levels, which were constantly full of audiences. Even, they were willing to buy tickets to enter the venue and watch the biggest vocal music competition at that time [36]. In the early development of Indonesian music, the portrait of vocal music competitions along with symphony orchestra accompaniment was an extraordinary one [37].

Ultimately, through Bintang Radio Contest, Indonesian singers resided in the hearts of public. In addition, they also have an opportunity to develop their talents, so that they could achieve a better living standard. Meanwhile, pop music became the most popular category compared to seriosa and keroncong [38]. Pop music was indeed adapted from popular music in America and Europe, nevertheless, pop music in Bintang Radio Contest derived to pop music which has been processed and has its authentic 
character; the clear distinction was using Indonesian translation for the lyrics [39]. One of the pop singers known by melodious voice and distinctive style was Titiek Puspa [40]. She has never won first place in Bintang Radio Contest both in regional and national level. However, because of her melodious voice, as requested by Sjaiful Bahri, she got the opportunity to sing in Malam Panggung Gembira, this was led her to become a famous singer [41].

\section{Significance for the Development of Indonesian Music}

Bintang Radio Contest has produced star-singers, namely: Sam Saimun, Bing Slamet, Andi Mulja, Ping Astono, Norma Sanger, Mien Sondakh, Rosita Suprapti, Tubagus Sanusi, and so forth, known by the Indonesian people [42]. Some figures, such as Marjati (Surakarta), Sajekti (Surakarta), Suprapti (Surakarta), Ishmanto (Surakarta), Djanad (Yogyakarta), Djauhari (Yogyakarta), Mudjiwarti (Yogyakarta), and Surip (Yogyakarta), were also known as keroncong singers. Those figures broadcasted in RRI Surakarta and Yogyakarta nearly every day [43]. Apart from the aforementioned, this competition also created a prominent Javanese singer, namely Waldjinah. She participated in Bintang Radio Contest in the ex-Surakarta Residency Level since 1959 and became the first winner in Bintang Radio Contest for keroncong category in 1965 [44].

Bintang Radio Contest has also create the first generation of composers, songwriters, orchestrators or arranger, conductor, and accompaniment pianists. Some figures, such as Sjaiful Bachri, Iskandar, Isbandi, Sutedjo, Suwandi, E. Sambayon, and Samsidi were famous orchestra leaders at that time. Meanwhile, there were also some favorite piano players were respected by many singers, for instance: Harry Mulyono, Mochtar Embut, and Sudharnoto [45]. Samsidi and Sudharnoto were musical figures who made their debut from Solo Hoso Kyoku, after the Indonesian independence, the name was changed to RRI Surakarta.

Bintang Radio Contest has also create the first generation of Indonesian popular music. Except for the keroncong category which was directly accompanied by a keroncong ensemble, at the preliminary stage selection, all singers were accompanied by a piano. Only at the final level, all the finalists, including keroncong, seriosa, and pop music, were accompanied by a complete orchestra consisting of 30-40 players. For the early development of music in Indonesia in 1950s, the portrait of vocal music competitions with symphony orchestra accompaniment was extraordinary. Each provincial capital has two to three studio orchestra or radio orchestra for keroncong, pop music and serious music which also played Western classical music [46]. For example, since 1950 RRI Surakarta has had a studio orchestra or radio orchestra whose members come from Surakarta Radio Orchestra (founded in 1943), they did broadcasts on Solo Hoso Kyoku. Based on Lokananta's records list from 1957-1971, RRI Surakarta has a studio orchestra or radio orchestra called Orkes Studio Surakarta (seriosa), Orkes Kroncong Asli Studio Surakarta (original keroncong and Javanese style), and Radio Orkes Surakarta (new keroncong and pop music) [47].

Bintang Radio Contest held in 1950s, marked as the emergence of Indonesian popular songs, techniques, and singing styles. Except for keroncong music, both in terms of style and song - the songs presented at Bintang Radio Contest took lessons from popular music from America and Europe. However, the adaptation of the influence was successfully processed into its own distinctive style [48].

In its release of the annual Bintang Radio Contest in RRI from 1951 onwards, the magazine of Mimbar Indonesia demonstrated the significant role of RRI in encouraging and promoting the search for Indonesian music during that time [49]. On the other hand, Indonesian society's viewpoint, Bintang Radio Contest in the early 1950 s became a vehicle for Indonesians to explore music in a more general, direct, and open way. Music, which formerly listened by limited circle, could be enjoyed by anyone, anytime, and anywhere through radio [50].

\section{Conclusion}

Based on the preceding discussion in the previous sections, it could be seen that Bintang Radio Contest organized by RRI was an effort to shape Indonesia's national culture. Through Bintang Radio Contest, RRI attempts to answer questions that arose at the beginning of Indonesia's independence, namely: "Where is our culture going?". Through this event, it was expected that a national culture could be formed, especially in the field of music and vocal arts, which at that time was one of the aspects discussed by political figures, cultural experts, and artists in relation to efforts in building Indonesian national culture. Bintang Radio Contest in 1950s has become a sign of the revival of music in Indonesia which was expected to become a national identity.

\section{References}

[1] Betts, Raymond (2004) Decolonization via Els Bogaerts (2011) “'Kemana arah kebudajaan kita’ Menggagas Kembali Kebudayaan di Indonesia pada Masa Dekolonisasi”, in Jennifer Lindsay and Maya H.T. Liem, eds., Ahli Waris Budaya Dunia: Menjadi Indonesia, 1950-1965. Denpasar - Jakarta: Pustaka Larasan \& KITLV: 256.

[2] Sen, Krishna and David T. Hill (2000) Media, Culture, and Politic in Indonesia. Oxford University Press: 82-84.

[3] Kementerian Penerangan (1953) Sejarah Radio di Indonesia. Djakarta: Djawatan Radio Republik Indonesia: $253-254$.

[4] Yampolsky, Philip (1987) Lokananta A Discography of the National Recording Company of Indonesia 1957-1985. Madison, Wisconsin: Center for Southeast Asian Studies University of Winconsin: 10-12.

[5] Sutton, R. Anderson (1991) Traditions of Gamelan Music in Java: Musical Pluralism and Regional Identity. Cambridge: Cambridge University Press.

[6] Mardianto, Herry and Antonius Darmanto (2001) Tradisi Sastra Jawa Radio. Yogyakarta: Penerbit Kalika.

[7] Puguh, Dhanang Respati (2015) "Mengagungkan Kembali Seni Pertunjukan Tradisi Keraton: Politik Kebudayaan Jawa Surakarta, 1950an-1990an". Disertasi pada Program Studi Ilmu-Ilmu Humaniora (Sejarah) Program Pascasarjana Fakultas Ilmu Budaya Universitas Gadjah Mada; Puguh, Dhanang 
Respati (2017) "Radio Republik Indonesia Surakarta, 1945-1960s: Its Role in Efforts to Maintain Indonesian Independence and the Formation of National Culture", Indonesian Historical Studies 1 (2): 138-153.

[8] "Tradisi RRI Mengabdi: Kata, Seni, dan Irama untuk Kebebasan Bangsa”, Berita Radio, September 1955: 3.

[9] Puguh, Dhanang Respati (2015) "Mengagungkan Kembali Seni Pertunjukan Tradisi Keraton: Politik Kebudayaan Jawa Surakarta, 1950an-1990an". Disertasi pada Program Studi Ilmu-Ilmu Humaniora (Sejarah) Program Pascasarjana Fakultas Ilmu Budaya Universitas Gadjah Mada: $117-120$.

[10] Puguh, Dhanang Respati (2015) "Mengagungkan Kembali Seni Pertunjukan Tradisi Keraton: Politik Kebudayaan Jawa Surakarta, 1950an-1990an". Disertasi pada Program Studi Ilmu-Ilmu Humaniora (Sejarah) Program Pascasarjana Fakultas Ilmu Budaya Universitas Gadjah Mada: $122-126$.

[11] Dewantoro, Ki Hadjar, "Pembangunan Kebudajaan Nasional: Sekedar Petundjuk", Mimbar Indonesia, Nomor Kemerdekaan (33), 17 Agustus 1948: 1617.

[12] Puguh, Dhanang Respati (2015) "Mengagungkan Kembali Seni Pertunjukan Tradisi Keraton: Politik Kebudayaan Jawa Surakarta, 1950an-1990an". Disertasi pada Program Studi Ilmu-Ilmu Humaniora (Sejarah) Program Pascasarjana Fakultas Ilmu Budaya Universitas Gadjah Mada: $127-131$.

[13] Majur, Gusti, "Meneropog Kongres Kebudajaan Nasional Indonesia”, Mimbar Indonesia, No. 37 Tahun II, 11 September $1948: 26$.

[14] Supardi, Nunus (2007) Kongres Kebudayaan (1918-2003). Yogyakarta: Ombak: 148

[15] Bogaerts, Els (2011) “Kemana arah kebudajaan kita’ Menggagas Kembali Kebudayaan di Indonesia pada Masa Dekolonisasi”, in Jennifer Lindsay and Maya H.T. Liem, eds., Ahli Waris Budaya Dunia: Menjadi Indonesia, 1950-1965. Denpasar - Jakarta: Pustaka Larasan dan KITLV: $257,267-285$.

[16] Supomo, "Soal Politik Kebudajaan", Mimbar Indonesia, No. 48 Tahun V, 1 Desember 1951: 3 and 26.

[17] Jones, Tod (2005) "Indonesian Cultural Policy, 1950-2003: Culture, Institutions, Government". Thesis is presented for the Degree of Doctorate of Philosophy of Curtin University of Tehnology Perth: 95-96.

[18] "Perkembangan Perlombaan Djuara Bintang Radio", Berita Radio, September 1955: 27.

[19] Kristanto, P. "Para Vokalis di Siaran Radio IV", Berita Radio, September 1954: 5.

[20] Kristanto, P. "Para Vokalis di Siaran Radio IV", Berita Radio, September 1954: 5.

[21] "Perkembangan Perlombaan Djuara Bintang Radio", Berita Radio, September 1955: 27.

[22] Kristanto, P. "Para Vokalis di Siaran Radio III", Berita Radio, September 1954: 4.

[23] "Perkembangan Perlombaan Djuara Bintang Radio", Berita Radio, September 1955: 28.

[24] "Perkembangan Perlombaan Djuara Bintang Radio", Berita Radio, September 1955: 28; Hardjana, Suka (2003) Corat-coret Musik Kontemporer Dulu dan Kini. Jakarta: Ford Foundation \& Masyarakat Seni Pertunjukan Indonesia: 222-223.

[25] "Perkembangan Perlombaan Djuara Bintang Radio", Berita Radio, September 1955: 27.

[26] "Bintang Radio Tahun 1965", Minggu Pagi, No. 19, Tahun XVII, 8 Agustus 1965: 7.

[27] "Bintang Radio 1952", Nasional, No. 38 Th III, 20 September 1952: 18-19.

[28] Darmosoegondo, "Pemilihan Bintang Radio di Daerah", Berita Radio, Agustus 1954: 8.

[29] "Bintang Radio Tahun 1965", Minggu Pagi, No. 19, Tahun XVII, 8 Agustus 1965: 7-8.

[30] Hardjana, Suka (2003) Corat-coret Musik Kontemporer Dulu dan Kini. Jakarta: Ford Foundation \& Masyarakat Seni Pertunjukan Indonesia:Hardjana: 224.

[31] "Program Siaran Studio-Studio Manunggal”, Berita Radio, 1954-1956: passim.

[32] “Bintang² Radio 1955", Star Weekly, No. 507, 17 September 1955: 8.

[33] Darmosoegondo, "Pemilihan Bintang Radio di Daerah", Berita Radio, Agustus 1954: 8.

[34] "Perkembangan Perlombaan Djuara Bintang Radio", Berita Radio, September 1955: 28

[35] "Bintang ${ }^{2}$ Radio 1955", Star Weekly, No. 507, 17 September 1955: 8.

[36] "Perkembangan Perlombaan Djuara Bintang Radio", Berita Radio, September 1955: 28.

[37] Hardjana, Suka (2003) Corat-coret Musik Kontemporer Dulu dan Kini. Jakarta: Ford Foundation \& Masyarakat Seni Pertunjukan Indonesia:Hardjana: 224.

[38] "Musik Hiburan dan Penggemarnja", Minggu Pagi, 29 September, 1963: 25.

[39] Hardjana, Suka (2003) Corat-coret Musik Kontemporer Dulu dan Kini. Jakarta: Ford Foundation \& Masyarakat Seni Pertunjukan Indonesia: 224; "Musik Hiburan dan Penggemarnja", Minggu Pagi, 29 September, 1963: 25.

[40] "Musik Hiburan dan Penggemarnja", Minggu Pagi, 29 September, 1963: 25.

[41] “40 Tahun Karier Titiek Puspa: Titiek Puspa Sang Legenda”, Kompas, 4 Juli 1993: 6

[42] "Tradisi RRI Mengabdi: Kata, Seni, dan Irama untuk Kebebasan Bangsa", Berita Radio, September 1955: 4

[43] Kristanto, P. "Para Vokalis di Siaran Radio, Berita Radio, Agustus 1954: 4.

[44] Wijaya, Parenta (2008) "Kehidupan Musik Keroncong Langgam Jawa di Surakarta, 1959-1994". Skripsi Jurusan Ilmu Sejarah Fakultas Ilmu Budaya Universitas Gadjah Mada: 86; Sartono, Frans, "Persona Waldjinah: Legenda Si Walang Kekek", Kompas, 23 Maret 2010: 23; Efix, "Waljinah Si Walang Kekek: Nyanyi Sambil Nunggu Hokkie", Kompas, 24 Juni 1979: 1.

[45] Hardjana, Suka (2003) Corat-coret Musik Kontemporer Dulu dan Kini. Jakarta: Ford Foundation \& Masyarakat Seni Pertunjukan Indonesia: 224.

[46] Hardjana, Suka (2003) Corat-coret Musik Kontemporer Dulu dan Kini. Jakarta: Ford Foundation \& Masyarakat Seni Pertunjukan Indonesia: 224.

[47] Yampolsky, Philip (1987) Lokananta A Discography of the National Recording Company of Indonesia 1957-1985. Madison, Wisconsin: Center for Southeast Asian Studies University of Winconsin: 69-78.

[48] Hardjana, Suka (2003) Corat-coret Musik Kontemporer Dulu dan Kini. Jakarta: Ford Foundation \& Masyarakat Seni Pertunjukan Indonesia: 224.

[49] Bogaerts, Els (2011) “'Kemana arah kebudajaan kita’ Menggagas Kembali Kebudayaan di Indonesia pada Masa Dekolonisasi”, in Jennifer Lindsay and Maya H.T. Liem, eds., Ahli Waris Budaya Dunia: Menjadi Indonesia, 1950-1965. Denpasar - Jakarta: Pustaka Larasan \& KITLV: 275.

[50] Hardjana, Suka (2003) Corat-coret Musik Kontemporer Dulu dan Kini. Jakarta: Ford Foundation \& Masyarakat Seni Pertunjukan Indonesia: 223. 